\title{
Bilateral Trade Between China and Kazakhstan: Challenges and Opportunities in the Context of Belt and Road Initiative
}

\begin{abstract}
Yuhang Duan ${ }^{1}$
${ }^{1}$ Qingdao No.66 Middle School Shandong Province 266000 China,

Email: DUANYUHANG2020@126.com

ABSTRACT

The trade and cooperation between China and Kazakhstan has been based on a shared commitment as the total trade volume increases continuously. However, in general, the commercial and commodity structure is still a single product structure, with labor-intensive products and raw material exports as the the main types of trade. Due to the development direction and economic development situation of Xinjiang, the Chinese province that borders on Kazakhstan, the proportion of high-tech content and high value-added products is relatively small. With the development of the "Belt and Road", the trade between China and Kazakhstan is also continuing to deepen, specifically presenting in economy, investment, trade and regulation of related policies. The two countries have reached consensus on development and shared a common understanding promoting the economic development of the two countries. However, in practical cooperation and communication, due to various factors such as the unbalanced regional development, there also exist certain issues and problems. Despite the existing problems due to the different economic systems and economic development, the two countries still shares great expectation in future development. With the continuous strengthening bond, the trade between China and Kazakhstan always maintains a rapid growth. Under such background, it is necessary to conduct strategic researches and analyses on the problems arising from the trade between the two countries.
\end{abstract}

Keywords: One Belt One Road, trade, countermeasure research

\section{INTRODUCTION}

China and Kazakhstan's fruitful cooperation in the field of import and export trade under the "Belt and Road Initiative" has made not only China surpass Russia as Kazakhstan's largest trading partner, but also Kazakhstan as China's most important business partner in Central Asia. Based on the 2003-2017 China Kazakhstan trade HS quarterly data, the overall characteristics and product structural characteristics of China's Kazakhstan trade cooperation and the main influencing factors indicate that: influences of factors such as the total economic scale of the two countries, the level of GDP per capita, tariff rates, the international financial crisis, the "Belt and Road" initiative, etc on the total trade volume and main product trade are different, showing the complexity of trade influence factors; the complementary trade of traditional industries between China and Kazakhstan will continue to expand, improving the industrial structure of bilateral trade while promoting the integration of bilateral trade and investment should become the developing direction of trade and economic relations between China and Kazakhstan. It is foreseeable that with the advancement of the "Belt and Road", China and Kazakhstan's cooperation and development prospects in the field of trade and investment will become more and more broad.

\section{THE CURRENT TRADE STATUS BETWEEN CHINA AND KAZAKHSTAN UNDER THE BACKGROUND OF THE "BELT AND ROAD"}

Kazakhstan is developing steadily. Although it was part of the former Soviet Union and has been in a state of turmoil since the former Soviet Union split, making its import and export volume relatively small compared to its counterpart countries, yet after more than ten years of development, long-time coexistence with the "Belt and Road", Kazakhstan has made great strides in its own economic and trade development, and its imports and exports have also been rising. At the same time, in terms of overall development, China and Kazakhstan's 
cooperative trade has also achieved more in-depth development, especially the developments in economy and trade. Through the growing trade volume of the two countries, the development trend of the two countries in trade can be seen clearly. The scale of bilateral trade is constantly increasing. According to the statistics, the growth of bilateral trade has been very strong since 2002, especially since it has exceeded 10 billion US dollars in 2007. China's trade status in Kazakhstan has become more important, and the share of trade with China in Kazakhstan's total trade is increasing day by day.

At the same time, the field of trade and investment is also expanding. According to data analysis, China's investment in Kazakhstan is mainly divided into oil exploration and extraction, gas station, networking, and agricultural product processing. At the same time, Kazakhstan's investment in China is mainly distributed in Xinjiang Province where regional trade exchanges present characteristics such as closeness, showing fatigue and weakness in subsequent development. In terms of policy support, development in the relation between China and Kazakhstan also has strong policy support. Based on the good communication and discussion between China and Kazakhstan, the Economic and Trade Agreement, the Investment Protection Agreement, the Commodity Inspection Agreement, and the Automotive The "Transport Agreement", "Railway Transit Transport Agreement" and other policies have been signed successively, escorting the economic and trade relations between the two countries and making long-term and indepth development in economic and trade development possible between the two countries.

\section{ISSUES ARISING FROM THE TRADE BETWEEN CHINA AND KAZAKHSTAN}

With the development of the "Belt and Road", the trade between China and Kazakhstan has also continued to deepen, which is manifested in economy, investment, trade and regulation of related policies. Agreement on the future development has already been achieved and the shared understanding and commitment have great influence on the development of two countries' economy. However, during the cooperation and communication, due to various factors such as the uneven regional development, there are also problems.

\subsection{The laws and regulations on bilateral trade cooperation are not yet perfect}

With the continuous deepening of development, China and Kazakhstan have formed an economic community, and the two countries have a high degree of unification in economy. However, in the rapidly developing economic environment, the two countries are both in the process of transformation and improvement. The market mechanism and market monitoring system of the two countries are still in the development stage, and no sound system has been formed to supervise the trade process. All of them have different degrees of deficiencies, which has formed certain restrictions on the smooth development of bilateral trade cooperation. Since China's development is at a relatively good level, it has a relatively complete performance in the regulatory mechanism. On the contrary, Kazakhstan has shown a more loose state in the trade process where relevant government departments have greater arbitrariness in the enforcement process, customs clearance procedures are not standardized and gray customs clearance is prevalent. Usually frequent customs closures, tax inspections, tariff adjustments, and increased customs clearance costs have caused constant trade friction between China and Kazakhstan. In addition, Kazakhstan's market economy has weaker cooperation concepts and innovative capabilities, and many promulgated foreign policies lack coherence. In order to pursue political achievements, local governments sometimes take the expansion of economic aggregates as the core. In the case of unsound market mechanisms and the formation of "large and comprehensive" and "small and comprehensive" structures, direct investment is adopted. The pursuit of local economic growth has led to the establishment of barriers by local governments, which has narrowed the investment fields of both parties. Meanwhile, regional development is unbalanced. Due to the bias of regional policies, regions may be open under the protection or loosing of policies and regional adjustments to the government are prone to regional imbalances, resulting in a single and unbalanced trade environment.

\subsection{The geographical structure of bilateral trade cooperation is quite limited}

China and Kazakhstan have frequent trade exchanges, and the trade environment is constantly developing and becoming mature. However, judging from the development situation in 2016, the trade between Xinjiang and Kazakhstan consists of about $70 \%$ of the total trade between China and Kazakhstan while Xinjiang is one of the least developed provinces in China causing certain shortcomings in trade types. Relevant enterprises in China's more developed regions have less participation which cannot fully demonstrate the strength of China's economic development, and cannot promote the early transformation of the development of relations between China and Kazakhstan. Although the joint development of Xinjiang and Kazakhstan in China relies on geographical and cultural advantages, if the bilateral trade cooperation is limited to the mutual exchanges along their borders, the level and depth of development will inevitably be low, and the development potential and development space will also be extremely limited. It will eventually lead to insufficient stamina for bilateral trade cooperation. At the same time, with the continuous development of the economy, trade transactions must also be continuously upgraded and innovated, but trade transactions relying on 
geographical advantages are relatively more traditional types, unable to carry out sustainable development and keep up with the development of trade trend. The development with times is constantly progressing, but in the development process, due to its special geographical location, Xinjiang has shown a relatively slow development situation. Kazakhstan is also inland and has limitations in the means of contact with the outside world which makes it not able to develop well.

\subsection{The unbalanced development of the commodity structure of bilateral trade cooperation}

Although the trade between China in Kazakhstan is continuously deepening, and the trade volume is also increasing, the overall commercial and commodity structure is still a single product structure trade type which is mainly made up of labor-intensive products and exports of raw materials. Due to the development direction and economic strength of Xinjiang, the proportion of hightech content products and high value-added products is relatively small. At the same time, for the processing industry, raw material processing and export are also the most important form of trade between the two countries. Through the import or export of raw materials and the corresponding processing, difference is obtained between the two. But in the development of the two, traditional processing industry and labor are heavily relied on. The long-term development of trade is more about the implementation of sustainable development, and traditional trade is not conducive to sustainable development. However, according to the statistics of the Kazakhstan Statistics Department, China's exports to Kazakhstan in 2007 were still mainly consumer goods, including electromechanical products, textiles, shoes, clothing, plastic products, etc.; China's imports from Kazakhstan mainly are crude oil, steel, scrap copper, scrap steel, aluminum, copper, etc. High-tech and high valueadded products account for a relatively small proportion in the trade between the two countries. The lack of structure can be clearly seen from the overall structure. On the surface, this is in line with the resource endowment advantages of the two countries, but in the long run, the low proportion of high value-added commodities in the trade structure will restrict the expansion of the scale of bilateral trade cooperation.

\subsection{Non-standard bilateral trade cooperation and chaotic trade order}

Kazakhstan is an economically transitional country in the nature of the country, and the domestic market mechanism has been improved and developed. Therefore, there are problems such as irregularity and disorder in various ways. The development of the country and the development of the economy need to rely on a more stable and more prosperous economic environment. The chaotic environment brings chaotic development. In the development of Kazakhstan, special trade modes were formed between the two countries under specific historical conditions, such as cross-border direct sales and travel purchase trade. Fake and inferior products that entered the Kazakh market through this special informal trade method has tinted the the image of Chinese products in Kazakhstan. Friction in road transportation often occurs as well. A large number of Chinese commodities have entered the Kazakh market through the "charter charter package", which is called "grey customs clearance" in Kazakhstan. Since goods imported through this nonstandard way do not have the normal customs clearance procedures by Kazakh customs, a large amount of Kazakhstan's tax are lost, which has a negative impact on the continued healthy and rapid development of bilateral trade, which will also affect future bilateral trade and bring certain constraints to the smooth development of future cooperation.

\section{RESEARCH ON TRADE ISSUES BETWEEN CHINA AND KAZAKHSTAN}

There are specific problems in the development of the trade between China and Kazakhstan. The two countries have certain problems due to the different economic system and different development level. However, the two countries still have more far-reaching prospects in development, accompanied by the continuously strengthened trade between the two countries. Trade between China and Kazakhstan has always maintained rapid growth. Under such an environmental background, it is necessary to conduct corresponding strategic research and analysis on the problems arising from the trade between the two countries.

\subsection{Starting from the middle and low-end consumer goods market. Cultivate and develop one's own brand products}

China and Kazakhstan develop rapidly in economy. The entire economic environment is in a vigorous development status. Both of them show a relatively unified aspect in market demand. There is always a huge gap in the demand for mechanical and electrical products, building materials, wood and other products. Overall market analysis and development should be carried out and specifically targeted marketing methods and product solutions should be put forward. At the same time, more effort should be made on market positioning of products, establishing their own brand, improving after-sales service, and strengthening brand strategy. Meanwhile, in the inspection of export products, more strict regulations are needed. In textiles, clothing, household appliances and other products, we must eliminate defective products, retain high-quality products, and firmly control the export procedure to ensure that the quality of exported products is high, making the trade between China and Kazakhstan 
presents a more high-end and high-quality overall situation in the overall product structure. At the same time, it is necessary to change the uniform production model of large quantities and small varieties, and develop the production model of small batches, multiple varieties and multiple specifications. Only by adopting such a development direction can we achieve sustainable development, focus on developing our own brands, and build national products, and then implement the overall improvement of the trade between China and Kazakhstan promoting the overall transformation and quality improvement, creating good product brand and company image.

\subsection{Guide the regularization of private enterprises and form a group of large international companies facing the Kazakh market}

For a long time, due to the influence of historical legacy factors such as the transition of the old and new economic systems of Kazakhstan, most of the foreign trade enterprises facing the Kazakh market in our country are small and medium-sized enterprises. Not only are there insufficient funds, but the manufactured products are very concentrated and similar. Because there are common competitors in the same industry, it is easy to produce vicious competition. This kind of competition is easy to disrupt the market order, making the entire market development environment continue to deteriorate, which is not conducive to the exchange and development of the overall economy and undermines the development of the trade between China and Kazakhstan.

Moreover, the waste of the overall resources and costs of the enterprises "going global" in our country has also caused chaos in the industry market of the country where the project is located, causing dissatisfaction among the local industry and the government. Under such a development situation, large international companies can lead the trend in the development of the market, so that the market can develop toward a more reasonable and fair situation in the development. At the same time, in terms of research and development capabilities, only international corporations with strong capital and strength can undertake such development tasks, and have the strength to compete with foreign companies and snatch the market. Hence, China needs and must break the boundaries between regions and sectors, encourage crossregional and cross-sector enterprise alliances, and cultivate the ability of enterprises to resist market risks in Kazakhstan.

\subsection{Establish Xinjiang's advantageous industries and accelerate the process of new industrialization in the port area}

Xinjiang, situated in Northwest China is bordered by Kazakhstan, and the two countries have 7 first-class ports that are open to third countries, including Alashan Port land (railway, road) port, Khorgos land road (highway) port, and Baktu land road (highway) port. International transport status has created opportunities for China and Kazakhstan to conduct direct border trade. Therefore, Xinjiang should establish a westward export processing base and a commodity distribution center, actively cultivate and develop advantageous industries and leading enterprises, and focus on supporting products with advantages and characteristics such as cotton and linen textile industry, tomato and fruit processing industry, electromechanical, petroleum and petrochemical. The production and export of other products, nurture and support the development of leading enterprises towards outward-oriented enterprises, accelerate the process of new industrialization in port areas, and improve the structure of export commodities.

\section{CONCLUSION}

Carrying out bilateral trade cooperation between China and Kazakhstan will not only help promote the economic development of the two countries. It brings tangible benefits to the people of the two countries as well and plays an important role in promoting nongovernmental communications and guaranteeing the stability of the two countries, especially the border areas. At the same time, the economy of the two countries has continued to deepen in the course of trade development, creating a richer economic development environment for the two countries. Aalso, Xinjiang, being the most active trade area with Kazakhstan based on geopolitical advantages, is developing at a stable pace due to its special trade status and also China's special assistance and development plan, which is conducive to the balanced development various regions of China, promotes the optimization of the domestic economic environment, and promotes the enrichment of the overall environment and industrial structure. Certain problems have occurred in the trade process between the two countries, which has affected the development of the two countries in a more profound environment in trade cooperation. However, both countries are constantly striving to deepen their development to promote overall development and brand building. Establishing related enterprises, and accelerating the industrialization process are related strategies to solve the problems encountered in the development of the trade between the two countries. China and Kazakhstan have historically developed close trade relations and have a convenient regional advantage in regional cooperation. The implementation of trade cooperation can better leverage the advantages of the two 
countries into a higher quality economic environment and promote the economic development of the two countries.

\section{REFERENCES}

[1] Maukayeva Saule,Karimova Saya. Epidemiologic character of COVID-19 in Kazakhstan: A preliminary report.[J]. Pubmed,2020,7(3).

[2] Seda Yıldırım, Ayfer Gedikli, Seyfettin Erdoğan, Durmuş Çağrı Yıldırım. Natural resources rentsfinancial development nexus: Evidence from sixteen developing countries[J]. Elsevier Ltd, 2020, 68.

[3] Yang Yaxiong. Construction of China's Kazakhstan land border crossings in the new era and its synergistic effect $[\mathrm{J}]$. Journal of Northern Nationalities University, 2020(03): 14-22.

[4] Fomichev Alexander A, Marusik Yuri M. Notes on the spider genus Segestria Latreille, 1804 (Araneae: Segestriidae) in the East Palaearctic with description of three new species. [J]. Pubmed, 2020, 4758(2).

[5] Immunology-Immunoglobulins; New Immunoglobulins Study Results from R. Liu et al Described (Characterization of Ebinur Lake Virus and Its Human Seroprevalence at the ChinaKazakhstan Border)[J]. Information Technology Newsweekly, 2020.

[6] Guo Yan. China's border trade in Kazakhstan is "spring is strong" [J]. China's foreign trade, 2019 (05): 39-40.

[7] Liu Ying, Wang Weiran. The Impact of China's Kazakhstan's Bilateral Trade on Kazakhstan's Economy[J]. Eurasian Economy, 2019(02): 22$34+125+127$.

[8] Zhang Mei, Li Tao, Hou Junwen. Analysis of the bilateral trade structure of China Kazakhstan [J]. Chinese and foreign entrepreneurs, 2019(06)

[9] Yang Zhenzeng. China Kazakhstan Horgos International Border Cooperation Center Offshore RMB Business Development Research[J]. Eurasian Economics, 2018(02):53-62+125-126+128.

[10] Baigarina Aigerim (Sabina). Research on the development of China's agricultural trade in Kazakhstan under the background of "One Belt and One Road" [D]. Northwest Univer sity, 2018. 